\title{
Adaptation of laboratory practices in a pharmacology course at a public university in Peru
}

\author{
J. Campos-Florián*, E. Mantilla-Rodríguez, R. Ybáñez-Julca, I. Quispe-Diaz \\ Department of Pharmacology, Faculty of Pharmacy and Biochemistry, National University of Trujillo, Peru
}

\author{
Keywords \\ Laboratory Practice \\ Practical Seminars \\ Teaching \\ Pharmacology \\ Peru
}

${ }^{*}$ Corresponding author:

jcamposf@unitru.edu.pe
Summary: The focus of this case study is the implementation of a pedagogical strategy to adapt the laboratory practices of the Pharmacology course in a Peruvian public university, where animals such as rats and mice are routinely used. Amid the COVID-19 pandemic, and the consequent virtualisation of the teaching-learning process, several academic challenges were posed. The 'Practical Seminars' have arisen as a pedagogical proposal that allows faculty to adapt to the conditions of society. They are designed based on selected articles that reflect experiments with drugs, where selected information is adapted, such as graphs, images and even videos. By posing analysis questions allows for students' previous knowledge to be checked; thus promoting an applied critical attitude to clinical situations. With this resource the faculty tried to recreate a significant space for self-learning. The results of students' partial evaluation reflects a performance similar to that of previous years of the course, with teaching staff accepting this modality well. Finally, a space for analysis was generated, in addition to dispensing with the use of experimental animals.

\section{Background and Context}

Peru, like other countries in the region, has been facing a health emergency. After only two months, the impact of the COVID-19 pandemic has changed the way of life and working life of all Peruvians (Government of Peru, 2020). The Ministry of Education proposed distance education in the country's universities (Ministry of Education Peru, 2020).

The Universidad Nacional de Trujillo/ National University of Trujillo addressed the challenge of virtual education and to guarantee academic continuity, by implementing the virtual platform, which has served as a support for the teachinglearning process (National University of Trujillo, 2020a; 2020b).

In South America, for the development of undergraduate pharmacology courses, animals are usually used for experimentation. Such experiments demonstrated effects of selected drugs through in vivo and in vitro activities. Two decades ago, the Department of Pharmacology began to question the use of experimental animals, and as a result changes were made and dogs are no longer used in experiments.

Now, with the COVID-19 pandemic, faculty has had to speed up the process of refining the use of laboratory animals, which was intended to be achieved over the period of a few years. In the University there is no authorisation for face-toface activities for the remainder of the 2020 academic year. Due to this, the Department of Pharmacology returned to a proposal that was previously not very well accepted by all colleagues.

\section{Educational Description}

As mentioned, the Department had the challenge of virtualising the Pharmacology course, something that had not been previously done. With classes and conferences there was no difficulty due to the availability of technological tools already widely used (e.g. Google Meet), so this did not pose a major challenge. 
Learning 'by doing' is a strategy deeply rooted in the Pharmacy faculty at the University, but this is understood as 'doing' laboratory or field experimentation (Espíndola-Castro, 2011). In the virtual education mode, this was practically impossible, even though the Department had some pharmacology simulators (e.g. Pharmatutor, Rat Lab or OBS), as these did not cover all of the content in the syllabic proposal. In meetings between professors, the start of the Pharmacology course for this year was questioned, as it was not going to be possible to carry out laboratory-based practicals with experimental animals, which had been taking place for approximately eighty years. It was realised that there were two clear options: to adapt the curricular content or to adapt the teaching method. The latter was opted for.

Fourteen years ago, Practical Seminars were used for the first time in response to the shortage of biological material or chemical inputs; but the use of this pedagogical strategy was only occasional, and never involved the course in its entirety.

Practical Seminars are designed based on selected results of articles that reflect drug experiments. These are reflected in a document with graphs, tables, figures and even videos showing the sequence of an experiment. In addition to the typical contents of an academic document, such as introduction, objectives, there are questions. The didactic sequence has the following phases: 1) To investigate previous knowledge that allows to establish learning links; 2) Development of the practical seminar, with the resolution of the questions/issues, to check the validity of the learning, leading to the modification, expansion or replacement of initial knowledge; 3) Transfer of new knowledge in clinical situations; 4) Review, through the shared search for solutions. In this way, students' teaching-learning process would be guaranteed. With this, an attempt is made to take the student to a quasi-experiential setting, recreating a meaningful learning space; in addition to allowing the student to consider a cognitive conflict that constitutes a real challenge, which encourages their self-learning. The instructor teacher is there at all times during the practical session (through a group video call) to respond to doubts and concerns of the students. Finally, as in every academic session, a discussion of the questions raised occurs and the conclusions are dealt with.

In other universities in Peru, where courses in pharmacology are taught, they did not begin academic activities until after the pandemic had passed and they could return to conducting experiments with laboratory animals, arguing that this is the most significant form of learning for students.

\section{Outcomes and Recommendations}

In this case study, the Practical Seminars allowed the faculty to achieve the learning objectives expected from the students. At the time of writing the course is still in progress; the results of the partial evaluation reflect a similar performance to last year; there has been no dropout, except for the COVID-19 lockdown which forced some students to temporarily leave the course. The acceptance of this modality on the part of the teaching staff was good, moreover, as it did not change the contents of the course, and it did not require investing additional time in preparing new subjects for the practical part of the course. Also, embracing a rapid approach, the faculty had managed to adopt the 'three Rs' of Russell and Burch (1959), they have 'Reduced', they have 'Refined', and in part 'Replaced' the use of laboratory animals in the development of the practical part of the Pharmacology course.

It is possible that the University will return to the use of laboratory animals in the course, but this pandemic has taught us that it is possible to continue with curriculum development without the use of experimental animals. It will be necessary, at the end of the academic year, to achieve a balance between teachers and students and consider how this new strategy has affected students' academic experience. The positive aspect of the Practical Seminars was that there was more space for analysis and debate, as well as dispensing with the use of experimental animals. The negative aspect was the feeling that instructors had of doing very little, and on the part of the students who, for the moment, will not master specific experimental techniques involving the manipulation of experimental animals.

\section{References}

Espíndola-Castro, J.L. (2011). Reingeniería Educativa. Enseñar y aprender por competencias. Cengage Learning Inc. México.

Government of Peru [Gobierno del Perú]. (2020). Coronavirus en el Perú: casos confirmados Lima, Perú. Available at: https:// www.gob.pe/8662-coronavirus-en-el-peru-casos-confirmados

Ministry of Education Peru [Ministerio de Educación, Perú]. (2020). Superintendencia Nacional de Educación Superior Universitaria. Resolución Directiva $N^{\circ}$ 039-2020 - SUNEDO/CD. Available at: www.sunedu.gob.pe

National University of Trujillo [Universidad Nacional de Trujillo]. (2020a). Resolución de Consejo Universitario N 160-2020/UNT. Available at: http://transparencia.unitru.edu.pe/startbootstrap/

Russell, W.M.S., \& Burch, R.L. (1959). The Principles of Humane Experimental Technique. Johns Hopkins Bloomberg School of Public Health. Available at: https://caat.jhsph.edu/principles/theprinciples-of-humane-experimental-technique

Universidad Nacional de Trujillo. (2020b). Aula Virtual UNT. Available at: https://aulavirtual.unitru.edu.pe 